\title{
Colorectal Cancer TNM Finding v6
}

National Cancer Institute

\section{Source}

National Cancer Institute. Colorectal Cancer TNM Finding v6. NCI Thesaurus. Code C60833.

A finding about one or more characteristics of colorectal cancer, following the rules of the TNM AJCC v6 classification system. 